\title{
Solar Photovoltaic Assistance System Study for a Brazilian Light Rail Vehicle
}

\author{
Mariko de Almeida Carneiro ${ }^{1}$, Diogo da Fonseca Soares ${ }^{2}$ \\ ${ }^{1}$ ITL - Institute on Transport and Logistics, SAUS Q.1 - Bloco J - Entradas 10 e 20 Ed. Clésio \\ Andrade - CEP: 70070-944 - Brasília - DF, Brazil; CBTU - Brazilian Company of Urban Trains, \\ Praça Napoleão Laureano, Varadouro, João Pessoa - PB, Brazil (mariko.carneiro@gmail.com) \\ ORCID 0000-0002-7043-0618; ${ }^{2}$ TTL - Institute on Transport and Logistics, SAUS Q.1 - Bloco J - \\ Entradas 10 e 20 Ed. Clésio Andrade - CEP: 70070-944 - Brasília - DF, Brazil; CBTU - Brazilian \\ Company of Urban Trains, Praça Napoleão Laureano, Varadouro, João Pessoa - PB, Brazil \\ (diogosoares@id.uff.br) ORCID 0000-0001-5162-0793
}

\begin{abstract}
Recently, much research is being developed to improve sustainability in the transportation sector due to its impact on carbon dioxide $\left(\mathrm{CO}_{2}\right)$ production, climate change, and fossil fuel resources. Railways in the world have started to use solar power assistance to improve sustainability in the transportation sector. The Brazilian Company of Urban Trains operates a Brazilian Light Rail Vehicle (BLRV) for passenger transportation in Brazil. This article is a study on the potential of environmental and economic benefits of the installation of solar panels in the BLRV roof, operated in the urban metropolitan area of João Pessoa, to provide assistance on electric load. The results show that the installation of photovoltaic system in the roofs of the total fleet of BLRVs operated in João Pessoa railway can save about R\$ $800,000.00$ and reduce the emission of 540 tons of $\mathrm{CO}_{2}$ in 10 years.
\end{abstract}

Author Keywords. Solar Train, Photovoltaics, Brazilian Railway, Light Rail Vehicle.

Type: Research Article

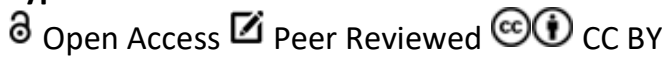

\section{Introduction}

In recent times, much research is being carried out to develop sustainable forms of the transportation to meet current needs without compromising the future generations to meet their demands (Rohollahi, Abdolzadeh, and Mehrabian 2015). This is necessary because of transportation sector impacts on carbon dioxide $\left(\mathrm{CO}_{2}\right)$ production, climate change, and fossil fuel resources. Since fossil fuels are fast depleting, besides being detrimental to the environment, there is a need to shift to renewable sources of energy.

Solar energy has gained importance in energy electricity markets due to decreasing in costs, favorable policies, and environmental concerns (Boampong and Brown 2020). Solar energy can be used for both electricity generation for the national grid through grid-tied photovoltaic topologies as well as in the transportation sector. Due to its availability and green aspect, the use of solar power assistance in the transportation sector is one strong path to reduce $\mathrm{CO}_{2}$ emissions. The applicability of renewable electricity such as photovoltaics is indicated to reduce the life cycle impact of suburban railways (Shinde et al. 2018).

The Brazilian Company of Urban Trains (CBTU), a public company, controls the urban rail system of Paraiba since 1984, among other four systems in Brazilian urban metropolitan areas. In Northeastern coast of Brazil, João Pessoa, the capital of Paraiba state, is served by 
CBTU rail system which connects the capital to three ore major municipalities of the metropolitan urban area in Paraiba state, Cabedelo, Bayeux and Santa Rita (Figure 1).
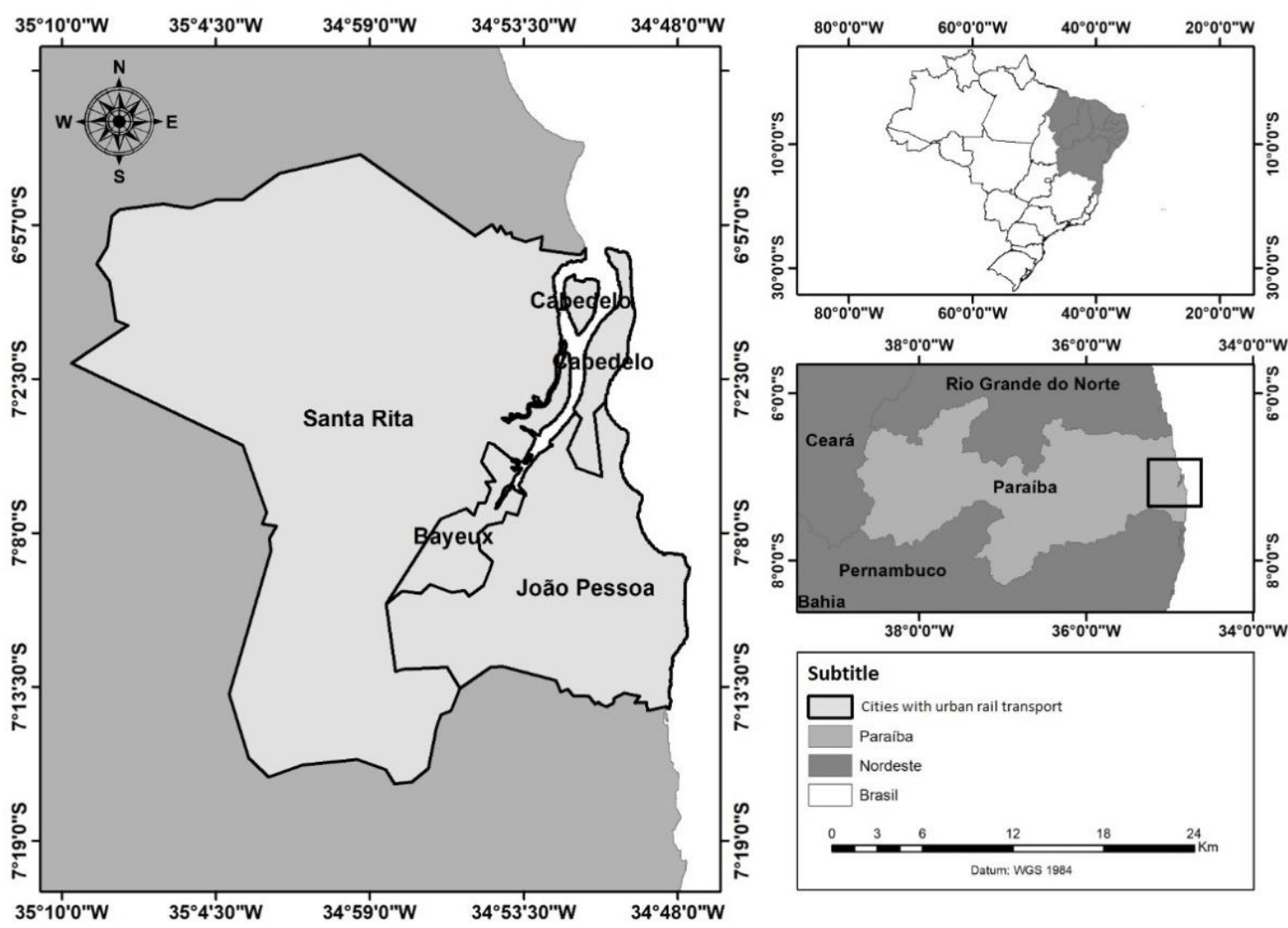

Figure 1: Location map of the municipalities served by João Pessoa Railway system (source: authors)

Given this scenario, a strategy for the João Pessoa rail system arises and is preparing to mitigate environmental impacts as much as provide economic benefits with an insertion of renewable technology in its rail system. Thus, this work aims to analyze the feasibility of solar photovoltaic assistance for a Brazilian Light Rail Vehicle (BLRV) João Pessoa railway.

To address this challenge it was developed a study on the potential of environmental and economical results of the installations of solar panels in the roof of BLRV operated in João Pessoa railway to provide assistance on electric load. Motivated by the background and literature review, this paper aims at answering the following questions:

1) Is it feasible to install solar photovoltaic modules on the BLRV rooftop to supplement the diesel generator sets with power?

2) Is the area available on the roof of the BLRV sufficient to meet the electrical lightening load through photovoltaic modules?

\section{Literature Review}

\subsection{Solar energy}

Since the beginning of the Industrial Revolution, problems involving the environment have been aggravated due to the explosion of excessive economic activity. The need for energy generation to sustainable socioeconomic development is also related to this imbalance between human activities and nature. Thus, it can be said that the production of electricity through renewable sources, emerges as a possible solution to achieve sustainable social development (Proença 2007). 
The consolidation of the use of photovoltaic energy as a viable source for energy generation has intensified over almost two centuries of history, marked by the search for more efficient materials for photo conversion, as well as reduction of costs, and increase of productivity. This tendency is due to the fact that photovoltaic energy is considered a source of clean energy, because there is no emission of pollutants during the process of generating energy, besides photovoltaic modules having a long useful life (Brito et al. 2010).

One of the factors that put the photovoltaic energy to advantage, when compared to other renewable sources of energy, is its range of application possibilities (Feitosa 2010). Currently, the installation of photovoltaic panels on the roofs of homes has become increasingly frequent in order to contribute to supply their energy demand, as well as the installation of solar poles intended for public street lighting. Another area that favors the application of photovoltaic energy is the agricultural sector, through so-called luminous traps, where energy from photovoltaic panels is used to power LED lamps, capable of attracting and capturing pests present in crops.

\subsection{Rail Solar Energy System in the world}

Railways among the world have started to use distributed photovoltaic generation (DPVG) for the traction power supply system (Zhong et al. 2020). However, few countries have successfully operated trains with solar photovoltaic (SPV) system on its rooftop. In Italy, amorphous silicon modules were installed on five passenger coaches, two locomotives, and three freight coaches (Trentini 1991). A study carried out in Iran, showed that $74 \%$ of the power requirement of a coach can be supplied by SPV system during hot months and $25 \%$ during cold months, with a maximum yield of $63.7 \mathrm{kWh}$ and an annual reduction of 37 tons of $\mathrm{CO}_{2}$ emission (Rohollahi, Abdolzadeh, and Mehrabian 2015). Another study in Pakistan, proposed solar power mass transit system to supply power using rail coaches due to the solar energy availability of and the energy shortage perspectives in the country (Jaffery et al. 2014).

In a study made by Indian Railways, the investment on solar photovoltaic modules atop train coaches can save 90,000 liters of diesel per year per train-set and also reduce 239 tons of $\mathrm{CO}_{2}$ emission per year per train with a return on investment of around 4 years (Shravanth Vasisht et al. 2017). More examples of trains supplied by photovoltaic energy are found in France and Italy (Shravanth Vasisht et al. 2017). Although some experiments of installing SPV system on trains were successful, the authors stated that until 2017 no scientific data was available in the public domain for further research and development of Solar Rail Coaches.

\section{3. $\mathrm{CO}_{2}$ emission and railway}

Climate change of anthropogenic origin is a widespread issue worldwide, international pacts such as the Kyoto Protocol in 1997, have been created to reduce the release of greenhouse gases. In Brazil, the National Policy on Climate Change was established by law No. 12,187 in 2009. The current global pact at the 21st Conference of Parties (COP21) of the United Nations Framework Convention on Climate Change (UNFCCC), known as the Paris Agreement in 2015, intends to strengthen the world's response to the threat of climate change, and strengthen countries' capacity to deal with the impacts of climate change (Soares 2017). An important outcome from Kyoto Protocol establishment is the increased patent application in renewable energy technologies in developing economies (Miyamoto and Takeuchi 2019).

The transportation sector is a major contributor to the global $\mathrm{CO}_{2}$ emission and global warming (Shravanth Vasisht et al. 2017). The state of Paraiba transportation system is the 
largest offender in terms of greenhouse gases (GHG) emissions (Soares 2017). The cargo and passenger transportation sector is the largest emitter of $\mathrm{CO}_{2}$ equivalent $\left(\mathrm{CO}_{2}\right.$-e) and with around $53 \%$ of the state's GHG emission.

Although railway is more environmentally friendly compared with other transportation modals like automobile and airplane, it is still characterized by intensive energy consumption and high pollution emission (Dalla Chiara et al. 2017). Many studies have shown the benefits of solar energy as a form of transforming railways in a clean transportation mode (Shinde et al. 2018; Vaičiūnas, Bureika, and Liudvinavičius 2016; Yang et al. 2019).

\section{Methodology}

\subsection{Case of study}

To check the feasibility of providing solar power assistance for BLRV for lighting and airconditioning, it is required to evaluate the performance of the BLRV. For this, the BLRV manufactured by BOMSINAL (Barbalha, CE, Brazil) and operated in João Pessoa Rail System was selected and details about various types of electrical loads, diesel consumptions of the generator cars, and area of roof-top available for installation of solar photovoltaic modules were collected.

The transition from source to destination has been termed as one trip. The route taken by the train consists in a $30 \mathrm{~km}$ trip from Cabedelo to Santa Rita that takes 60 minutes, as shown in Figure 2.

The focus of this work was to assist the power supply for the electrical load in the five BLRV of Brazilian Urban Trains Company (CBTU) operated in João Pessoa with a photovoltaic system to reduce cost with fuel and greenhouse gases emission.

The methodology for technical calculations were extracted from Shravanth Vasisht et al. (2017).

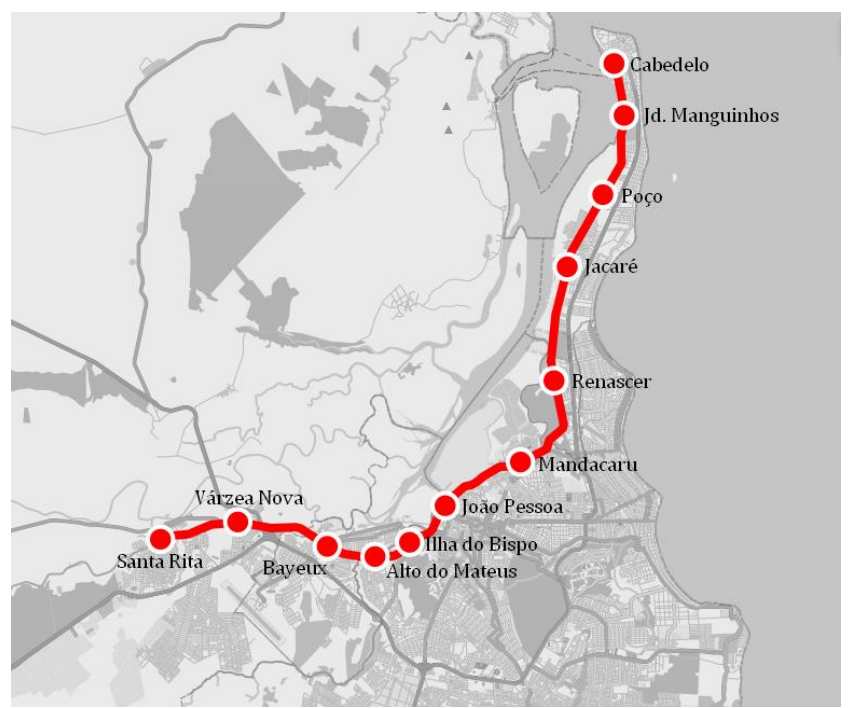

Figure 2: Route map of the train considered for case study - João Pessoa, Brazil (source: authors)

\section{Results}

\subsection{Technical aspects}

The BLRV provides two motor-generator sets that generate $100 \mathrm{~kW}$ each. Thus, the total generated power is $200 \mathrm{~kW}$. The exception is the BLRV 05 that features only $85 \mathrm{~kW}$ motorgenerator sets, generating a total power of $170 \mathrm{~kW}$. The energy consumption includes: six air conditioners of $15 \mathrm{~kW}$ each, 44 fluorescent lamps of $40 \mathrm{~W}$ and two fan motors of $2860 \mathrm{~W}$. In 
total, the nominal power consumption is $97.48 \mathrm{~kW}$. Hence, in one hour of operation, the nominal consumption of the BLRV is $97.48 \mathrm{kWh}$. However, the electric components are not always activated, so after a measurement made in sunny days (more usage of airconditioning), the average energy consumption was found to be about $27 \%$ of the nominal power of $26 \mathrm{kWh}$. To find out the fuel consumption for a power generation of $26 \mathrm{kWh}$, it was generated a correlation curve with field data from the BLRV, collected in several times of the days during different days of the week.

Considering Figure 3 , the curve generated estimates the fuel consumption to a given electric power. For a power consumption of $26 \mathrm{kWh}$, a fuel consumption of 8.7 liters per hour was calculated by extrapolation. As mentioned previously, a complete BLRV trip from the two final stations (Cabedelo to Santa Rita) takes about 60 minutes, or one hour. In this context, given the price of the fuel (diesel) of $R \$ 3.99$ in 2019, a BLRV trip costs $R \$ 34.83$ (8.7 liters/ hour $x \mathrm{R} \$ 3.99 /$ liter $\times 1$ hour).

To calculate the annual cost of diesel to provide electric load in one BLRV, it was considered that each BLRV works for an average of five hours per day, five days per week, being one day available for maintenance, and on Sundays the railway system is closed. Therefore, the total annual cost of diesel consumption for electric load in each BLRV is estimated to be $R \$$ $45,278.88$.

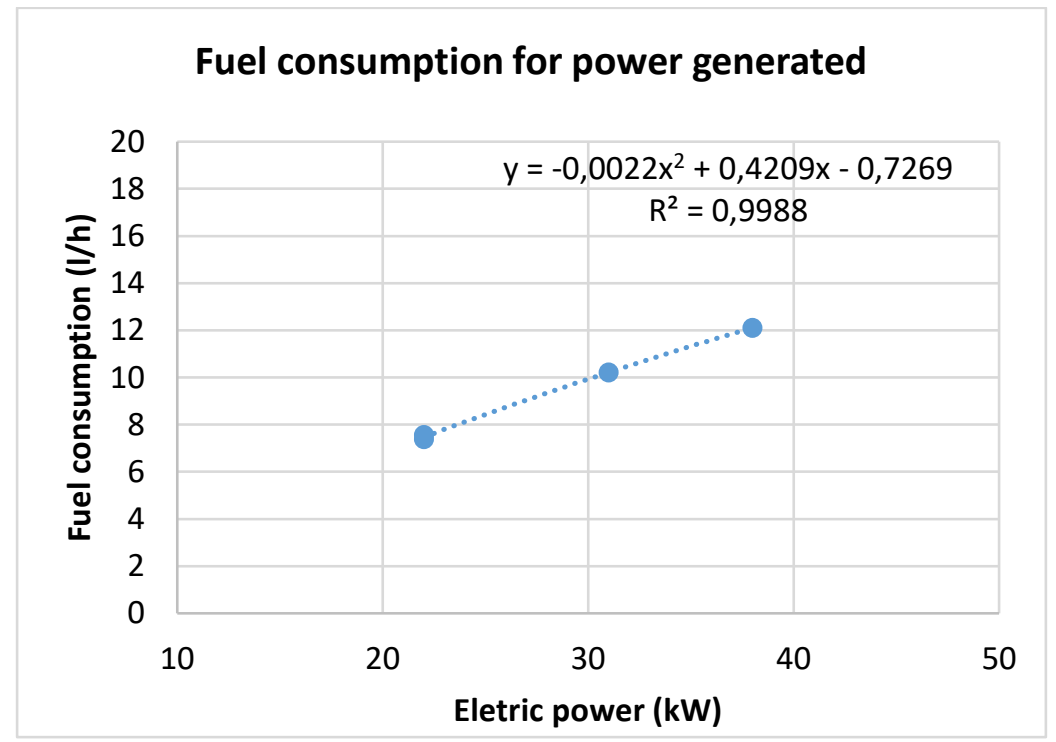

Figure 3: Curve relationship between fuel consumption and electric power in the BLRV (source: authors)

Each BLRV possess a roof area of $61 \mathrm{~m}^{2}$ available for solar panel installation. For a standard solar module of $1.984 \mathrm{~m}^{2}$ producing $370 \mathrm{~W}$ each, it will be possible to install 30 modules in each BLRV. The average period in João Pessoa with direct normal irradiance per day is 5 hours. Thus, applying Formula 1, the daily energy produced in a BLRV is estimated on 55.5 $\mathrm{kWh}$. That represents $43 \%$ of the energy consumed by the train operated during the 5 hours of direct normal irradiance, of $130 \mathrm{kWh}$. To find the potential diesel saved due to the photovoltaic system assistance it was used the curve showed in Figure 3, and a saving of approximately 15.85 liters of diesel per day was found. The annual saving for five days per week of operation, for each BLRV is about $R \$ 16,449.53$. Table 1 presents the train characteristics with solar panel.

$$
\text { Solar power electric generation: } D N I \times N \times P
$$

DNI: direct normal irradiance (hours) 
$\mathrm{N}$ : number of solar panel modules

$P$ : maximum nominal power of each module

\begin{tabular}{|c|c|}
\hline Name of the train & $\begin{array}{c}\text { Santa Rita-Cabedelo } \\
\text { BLRV }\end{array}$ \\
\hline Distance from source to destination & $30 \mathrm{~km}$ \\
\hline Duration of 1 Trip (source to destination) & 1 hours \\
\hline Total sunshine period during the day & 5 hours \\
\hline $\begin{array}{l}\text { Average electrical load measured in the trains } \\
\text { for comfort energy (per BLRV) }\end{array}$ & $26 \mathrm{kWh}$ \\
\hline $\begin{array}{l}\text { Details of the fuel used by generator } \\
\text { i. } \quad \text { Type of fuel used } \\
\text { ii. } \quad \text { Price per liter of fuel } \\
\end{array}$ & $\begin{array}{l}\text { Diesel B S-10 } \\
\mathrm{R} \$ 3,99\end{array}$ \\
\hline $\begin{array}{l}\text { Average fuel consumption by generator cars } \\
\text { for } 1 \text { trip }\end{array}$ & 8.7 liters \\
\hline $\begin{array}{l}\text { Expenditure on fuel for supplying for electrical } \\
\text { load during the trip }\end{array}$ & $\mathrm{R} \$ 34.83$ \\
\hline Roof-top area of the BLRV & $61 \mathrm{~m}^{2}$ \\
\hline $\begin{array}{c}\text { Solar power module characteristics: } \\
\text {-Nominal power } \\
\text {-Area }\end{array}$ & $\begin{array}{c}370 \mathrm{~W} \\
1.984 \mathrm{~m}^{2}\end{array}$ \\
\hline $\begin{array}{l}\text { Solar power electrical generation on each } \\
\text { BLRV per day }\end{array}$ & $55,5 \mathrm{kWh}$ \\
\hline $\begin{array}{l}\text { Average fuel reduction using the solar panels } \\
\text { per day }\end{array}$ & 15.85 liters \\
\hline $\begin{array}{l}\text { Total number of trips per train considering } 5 \\
\text { trips per day, } 5 \text { days per week, during the year }\end{array}$ & 1,300 \\
\hline $\begin{array}{l}\text { Fuel consumption costs for each BLRV per year } \\
\begin{array}{cl}\text { i. } & \text { with solar energy supply } \\
\text { ii. } \quad \text { without solar energy supply }\end{array}\end{array}$ & $\begin{array}{l}R \$ 28,829.35 \\
R \$ 45,278.88\end{array}$ \\
\hline
\end{tabular}

Table 1: Summary of BLRV and solar panel characteristics in João Pessoa railway

(source: authors)

The proposed design for the 30 modules of photovoltaic system to be installed in the BLRV is found in Figure 4. The roof area in the BLRV can provide up to $43 \%$ of the electric load, being not sufficient yet with the current solar photovoltaic technology available to provide all energy required to lighting and air-conditioning. But yet, it can save about $36 \%$ of diesel consumption. 


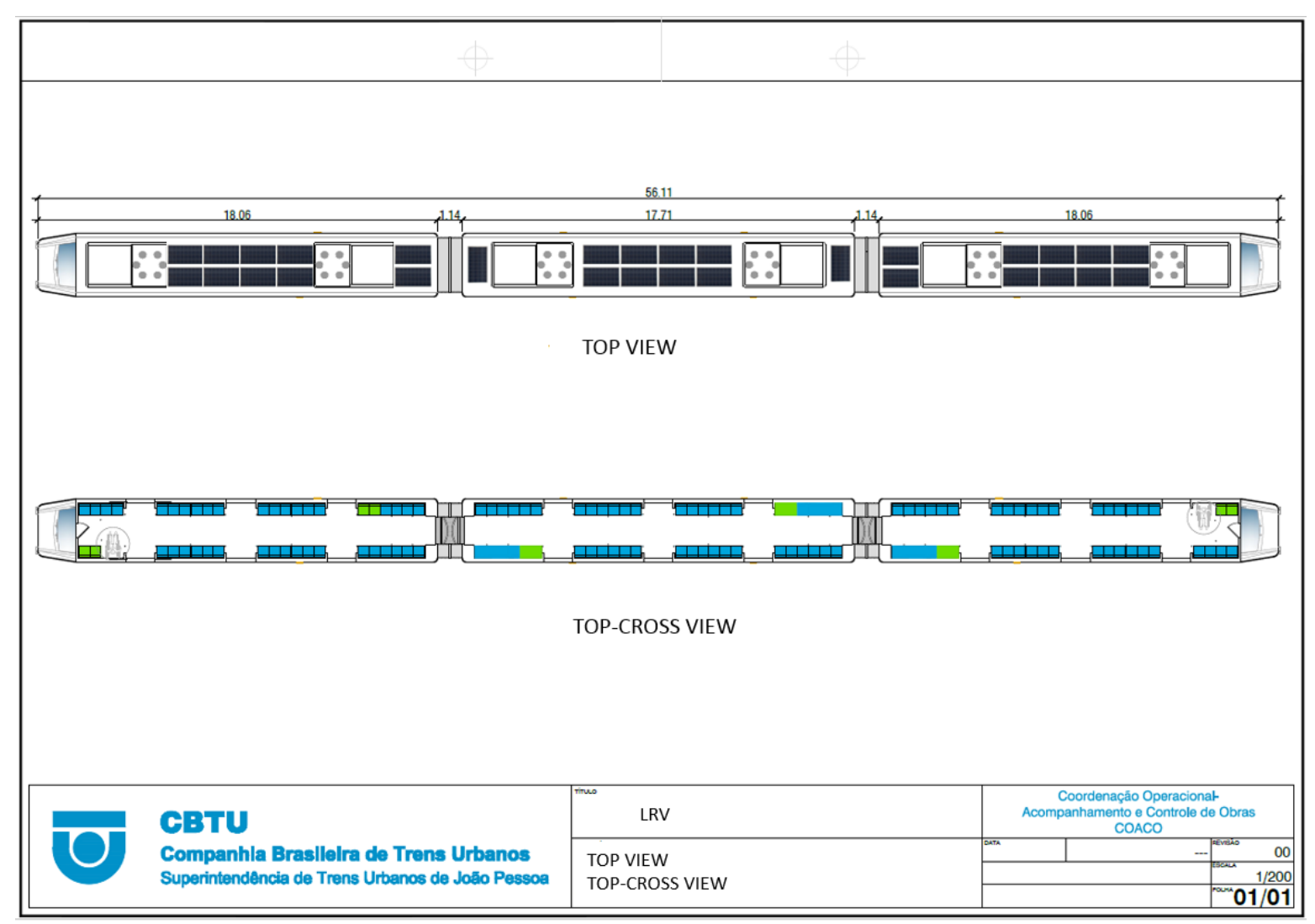

Figure 4: Proposed design of photovoltaic system in the BLRV

(source: authors)

\section{2. $\mathrm{CO}_{2}$ emission reduction}

The $\mathrm{CO}_{2}$ emission by diesel fuel of BLRV in João Pessoa railway system can be calculated by the sum of the results found in Formula 2 and Formula 3, based on GHG Protocol system.

The Formula 2 measures the equivalent $\mathrm{CO}_{2}$ emitted from pure diesel combustion. As the Diesel commercialized in Brazil is mixed with alcohol produced from organic matter, it is necessary to calculate also the emission of $\mathrm{CO}_{2}$ from alcohol combustion part.

$$
\mathrm{E}(\mathrm{t})=\mathrm{ECOF} \times \mathrm{GWP}_{-} \mathrm{CO}_{2}+\mathrm{ECHF}(\mathrm{t}) \times \mathrm{GWP}_{-} \mathrm{CH}_{4}+\mathrm{ENOF}(\mathrm{t}) \times \mathrm{GWP}_{-} \mathrm{N}_{2} \mathrm{O}
$$

On what;

$E(t)=$ Total emissions $\left(t \mathrm{CO}_{2}-\mathrm{e}\right)$

ECOF $=\mathrm{CO}_{2}$ emissions ( $\mathrm{t}$ ) fossil (The sum of all fossil fuels (liters or $\mathrm{m}^{3}$ ) $x$ Fossil fuel emission factor ( $\mathrm{kg} \mathrm{CO} 2$ / liter) / 1000

$\mathrm{ECHF}(\mathrm{t})=$ Emissions of $\mathrm{CH}_{4}(\mathrm{t})$ (The sum of any commercial fuel quantity (liters or $\mathrm{m}^{3}$ ) $\mathrm{x}$ Commercial Emission Factors ( $\mathrm{kg} \mathrm{CH}$ / liter) / 1000

Emissions of $\mathrm{N}_{2} \mathrm{O}\left(\mathrm{t}\right.$ ) (The sum of all commercial fuel quantities (liters or $\mathrm{m}^{3}$ ) $x$ Commercial Fuel Emission Factors ( $\mathrm{kg} \mathrm{N}_{2} \mathrm{O}_{4} /$ liter) 1000

$$
\mathrm{EB}(\mathrm{t})=\mathrm{FEB} \times \mathrm{SQB}
$$

On what;

$\mathrm{EB}(\mathrm{t})=$ Emissions of biogenic $\mathrm{CO}_{2}\left(\mathrm{t} \mathrm{CO}_{2}\right)$

$\mathrm{FEB}=$ Biofuel Emission Factor

$\mathrm{SQB}=\mathrm{It}$ is the sum of all biofuel amounts that exist in commercial gasoline required by Brazilian law in liters 
The results of the $\mathrm{CO}_{2}$ fuel combustion emission in João Pessoa railway system by the BLRVs are shown in Table 2. The total $\mathrm{CO}_{2}$ emission from fuel combustion is estimated of $1,048.82$ tons per year.

\begin{tabular}{cccccc}
\hline Source & FUEL & Qt. (liters) & tCO $-\mathrm{e}$ & $\begin{array}{c}\mathbf{t C O}_{2}- \\
\text { BIOMASS }\end{array}$ & Total tCO \\
\hline $\begin{array}{c}\text { Combustion of } \\
\text { fuel in BLRV }\end{array}$ & Diesel & 398.252 & 981,05 & 67,77 & $1,048.82$
\end{tabular}

Table 2: $\mathrm{CO}_{2}$ emission from fuel combustion in João Pessoa railway (source: authors)

However, only a part of the total $\mathrm{CO}_{2}$ emission from fuel combustion is released due to the electrical load supply for the BLRVs (e.g. air-conditioning and lighting) being the majority amount released to traction. Thus, the photovoltaic installation in all 5 BLRVs could result in a total reduction of $5.2 \%$ of $\mathrm{CO}_{2}$ emission, approximately, 54 tons of $\mathrm{CO}_{2}$ per year. Similar solar photovoltaic modules proposal for Indian Railways was estimated to reduce 239 tons of $\mathrm{CO}_{2}$ emission per year per train (Shravanth Vasisht et al. 2017), which is a much higher results compared to this study due to the higher length of the vehicle investigated in the study.

\subsection{Financial plan}

The business model assumes a partial replacement of the electric load of the Brazilian LRV in João Pessoa using solar panels. The capital expenditure (CAPEX) is composed of: solar Panels - $\mathrm{R} \$ 39.000,00$ for each BLRV, and infrastructure adjustments - $\mathrm{R} \$ 1,000.00$ for each BLRV.

The operational expenditure (OPEX) were estimated based on internal company parameters on $\mathrm{R} \$ 1,000.00$ / year for each BLRV for maintenance assignments.

In order to estimate the costs of contracting the solar panels, it was used the discounted cash flow method from the perspective of the service provider. For this, it was adopted the Brazilian interest rate of $6.75 \%$ yearly on 2018. For the solar panel cost, the interest rate was not applied due to the fact that the solar energy market is increasing in Brazil and the cost of solar power technology is decreasing.

\begin{tabular}{|c|c|c|c|c|c|c|}
\hline & 1 year & 2 year & 3 year & 4 year & 5 year & 10 years \\
\hline Investments & $\begin{array}{c}\mathrm{RS} \\
40,000.00\end{array}$ & $\begin{array}{c}\mathrm{R} \$ \\
80,000.00\end{array}$ & $\begin{array}{c}\mathrm{R} \$ \\
80,000.00\end{array}$ & $\begin{array}{c}\mathrm{R} \$ \\
80,000.00\end{array}$ & $\begin{array}{c}\mathrm{R} \$ \\
80,000.00\end{array}$ & $\begin{array}{c}\mathrm{R} \$ \\
80,000.00\end{array}$ \\
\hline $\begin{array}{c}\text { Cost } \\
\text { reduction }\end{array}$ & $\begin{array}{c}R \$ \\
16,449.53\end{array}$ & $\begin{array}{c}\mathrm{R} \$ \\
52,679.63\end{array}$ & $\begin{array}{c}\mathrm{R} \$ \\
93,725.84\end{array}$ & $\begin{array}{c}\mathrm{R} \$ \\
100,052.34\end{array}$ & $\begin{array}{c}\mathrm{R} \$ \\
106,805.87\end{array}$ & $\begin{array}{c}\mathrm{R} \$ \\
148,058.91\end{array}$ \\
\hline $\begin{array}{l}\text { Financial } \\
\text { Income }\end{array}$ & - & - & - & - & - & - \\
\hline Expenses & $\begin{array}{c}\mathrm{RS} \\
1,000.00\end{array}$ & $\begin{array}{c}\mathrm{R} \$ \\
3,202.50\end{array}$ & $\begin{array}{c}\mathrm{R} \$ \\
5,697.78\end{array}$ & $\begin{array}{c}\mathrm{R} \$ \\
6,082.38\end{array}$ & $\begin{array}{c}\mathrm{R} \$ \\
6,492.94\end{array}$ & $\begin{array}{c}\mathrm{RS} \\
9,000.00\end{array}$ \\
\hline Result & $\begin{array}{c}-R \$ \\
24,550.47\end{array}$ & $\begin{array}{c}-R \$ \\
56,730.49\end{array}$ & $\begin{array}{c}-R \$ \\
52,531.74\end{array}$ & $\begin{array}{c}\mathrm{R} \$ \\
37,892.32\end{array}$ & $\begin{array}{c}\mathrm{R} \$ \\
140,762.98\end{array}$ & $\begin{array}{c}\mathrm{R} \$ \\
890,405,84\end{array}$ \\
\hline
\end{tabular}

Table 1: Cash flow of BLRV solar system implementation (source: authors) 
The simplified cash flow, presented in Table 3, is intended to demonstrate the main components considered in the financial evaluation. The beginning of positive results starts between the third and the fourth year.

Table 4 and Table 5 below, show the total cost with electrical load for assistance in the five BLRV units for the next 10 years, from two perspectives:

\section{Considering the proposed new system}

\begin{tabular}{|c|c|c|c|c|c|c|}
\hline & 1 year & 2 year & 3 year & 4 year & 5 year & 10 years \\
\hline $\begin{array}{l}\text { Costs of } \\
\text { current } \\
\text { system }\end{array}$ & $\begin{array}{c}\mathrm{R} \$ \\
226,394.00\end{array}$ & $\begin{array}{c}\mathrm{R} \$ \\
241,676.02\end{array}$ & $\begin{array}{c}\mathrm{R} \$ \\
257,989.15\end{array}$ & $\begin{array}{c}\mathrm{R} \$ \\
275,403.42\end{array}$ & $\mathrm{R} \$ 293,993.15$ & $\mathrm{R} \$ 407,545.99$ \\
\hline $\begin{array}{c}\text { Costs of } \\
\text { new system }\end{array}$ & $\begin{array}{c}\mathrm{RS} \\
40,000.00\end{array}$ & $\begin{array}{c}\mathrm{R} \$ \\
80,000.00\end{array}$ & $\begin{array}{c}\mathrm{R} \$ \\
80,000.00\end{array}$ & & & $\mathrm{R} \$ 5.00$ \\
\hline $\begin{array}{c}\text { Costs } \\
\text { reduction }\end{array}$ & $\begin{array}{c}\mathrm{R} \$ \\
16,449.53\end{array}$ & $\begin{array}{c}\mathrm{RS} \\
52,679.63\end{array}$ & $\begin{array}{c}\mathrm{R} \$ \\
93,725.84\end{array}$ & $\begin{array}{c}\mathrm{R} \$ \\
100,052.34\end{array}$ & $\mathrm{R} \$ 106,805.87$ & $\mathrm{R} \$ 148,058.91$ \\
\hline $\begin{array}{c}\text { Total costs } \\
\text { (yearly) }\end{array}$ & $\begin{array}{c}\mathrm{R} \$ \\
249,944.86\end{array}$ & $\begin{array}{c}\mathrm{R} \$ \\
268,996.39\end{array}$ & $\begin{array}{c}\mathrm{R} \$ \\
244,263.31\end{array}$ & $\begin{array}{c}\mathrm{R} \$ \\
175,351.08\end{array}$ & $\mathrm{R} \$ 187,187.28$ & $\mathrm{R} \$ 259,492.09$ \\
\hline $\begin{array}{c}\text { Total } \\
\text { cumulative }\end{array}$ & $\begin{array}{c}-\mathrm{R} \$ \\
249,944.86\end{array}$ & $\begin{array}{c}-\mathrm{R} \$ \\
518,941.25\end{array}$ & $\begin{array}{c}-R \$ \\
763,204.56\end{array}$ & $\begin{array}{c}\mathrm{R} \$ \\
938,555.64\end{array}$ & $\begin{array}{c}\mathrm{R} \$ \\
1,125,742.92\end{array}$ & $\begin{array}{c}\mathrm{R} \$ \\
2,269,165.98\end{array}$ \\
\hline
\end{tabular}

Table 4: Total cost of BLRV with electrical load with photovoltaic assistance (source: authors)

\section{Keeping the current system}

\begin{tabular}{ccccccc}
\hline & $\mathbf{1}$ year & $\mathbf{2}$ year & $\mathbf{3}$ year & $\mathbf{4}$ year & $\mathbf{5}$ year & 10 years \\
\hline $\begin{array}{c}\text { Costs of } \\
\text { current } \\
\text { system }\end{array}$ & $\mathrm{R} \$$ & $\mathrm{R} \$$ & $\mathrm{R} \$$ & $\mathrm{R} \$ 275,403.42$ & $\mathrm{R} \$ 293,993.15$ & $\mathrm{R} \$ 407,545.99$ \\
\hline $\begin{array}{c}\text { Total } \\
\text { cumulative }\end{array}$ & $226,394.00$ & $\mathrm{R} \$ 1,676.02$ & $257,989.15$ & & & \\
\hline
\end{tabular}

Table 5: Total cost of BLRV with electrical load without photovoltaic assistance

(source: authors)

\section{Conclusions}

A study was taken with BLRV operated by the railway system of the metropolitan region of João Pessoa to investigate the proposal of implementing solar power for electrical assistance provided by solar panels installed in the roof of the BLRV. Environmental and economic benefits were identified as the most likely outcomes of the project. As economic benefit, it was estimated that $61 \mathrm{~m}^{2}$ of solar panels installed in each BLRV could potentially generate an average of $55.55 \mathrm{~kW}$ to be consumed for comfort energy, including air conditioning and lighting, and save about $\mathrm{R} \$ 822,107.35$ in ten years for the company, which is estimated to increase due to the durability of the panels to be around 25 years. As environmental benefit, the solar power system proposed in this study will reduce the emission of GHG, by up to 54 tons of $\mathrm{CO}_{2}$ per year to João Pessoa rail system.

Further studies can be applied to investigate the feasibility of installing the solar power system proposed in this study to the other railways systems in Brazil that currently operates 
similar BLRV, such as Recife, Maceio and Natal, which are bigger systems which solar system benefits can achieve much higher results.

Investments in renewable technology for railway system are expected to increase due to the impact of the transport sector on carbon dioxide $\left(\mathrm{CO}_{2}\right)$ production, climate change and fossil fuel resources. Hence, more studies on renewable sources and sustainable technologies are to be expected in order to reduce the railway industry's footprint.

\section{References}

Boampong, R., and D. P. Brown. 2020. "On the benefits of behind-the-meter rooftop solar and energy storage: The importance of retail rate design". Energy Economics 86 (february): Article number 104682. https://doi.org/10.1016/j.eneco.2020.104682.

Brito, M. A. G. de, G. Luigi, L. P. Sampaio, and C. A. Canesin. 2010. "Avaliação das principais técnicas para obtenção de MPPT de painéis fotovoltaicos". Paper presented in 9th IEEE/IAS International Conference on Industry Applications - INDUSCON 2010, São Paulo, Brazil, November 2010. https://doi.org/10.1109/INDUSCON.2010.5740002.

Dalla Chiara, B., D. De Franco, N. Coviello, and D. Pastrone. 2017. "Comparative specific energy consumption between air transport and high-speed rail transport: A practical assessment". Transportation Research Part D: Transport and Environment 52 (may): 22743. https://doi.org/10.1016/j.trd.2017.02.006.

Feitosa, P. H. A. 2010. "Energia solar no Brasil". Valor Econômico, March 24, 2010.

Jaffery, S. H. I., M. Khan, L. Ali, H. A. Khan, R. A. Mufti, A. Khan, N. Khan, and S. M. Jaffery. 2014. "The potential of solar powered transportation and the case for solar powered railway in Pakistan". Renewable and Sustainable Energy Reviews 39 (november): 270-76. https://doi.org/10.1016/j.rser.2014.07.025.

Miyamoto, M., and K. Takeuchi. 2019. "Climate agreement and technology diffusion: Impact of the Kyoto Protocol on international patent applications for renewable energy technologies". Energy Policy 129: 1331-38. https://doi.org/10.1016/j.enpol.2019.02.053.

Proença, E. D. R. B. 2007. "A energia solar fotovoltaica em Portugal: Estado-da-arte e perspectivas de desenvolvimento". Master's thesis, Instituto Superior Técnico, Technical University of Lisbon, Portugal. https://fenix.ist.utl.pt/dissertacoes/57014.

Rohollahi, E., M. Abdolzadeh, and M. A. Mehrabian. 2015. "Prediction of the power generated by photovoltaic cells fixed on the roof of a moving passenger coach: A case study". Proceedings of the Institution of Mechanical Engineers, Part F: Journal of Rail and Rapid Transit 229, no. $730-37$. https://doi.org/10.1177/0954409714524749.

Shinde, A. M., A. K. Dikshit, R. K. Singh, and P. E. Campana. 2018. "Life cycle analysis based comprehensive environmental performance evaluation of Mumbai Suburban Railway, India". Journal of Cleaner Production 188 (july): 989-1003. https://doi.org/10.1016/j.jclepro.2018.04.022.

Shravanth Vasisht, M., G. A. Vashista, J. Srinivasan, and S. K. Ramasesha. 2017. "Rail coaches with rooftop solar photovoltaic systems: A feasibility study". Energy 118 (january): 68491. https://doi.org/10.1016/j.energy.2016.10.103.

Soares, D. F. 2017. "Estimativa de emissão de gases de efeito estufa na operação do sistema ferroviário da região metropolitana de João Pessoa-Paraíba, Brasil". Master's thesis, Technology and Natural Resources Center, Federal University of Campina Grande, Paraíba, Brazil. http://dspace.sti.ufcg.edu.br:8080/jspui/handle/riufcg/1703. 
Trentini, M. 1991. "Photovoltaic systems for railways in Italy". Paper presented in 10th European Photovoltaic Solar Energy Conference, Lisbon, Portugal, April 1991. https://doi.org/10.1007/978-94-011-3622-8_211.

Vaičiūnas, G., G. Bureika, and L. Liudvinavičius. 2016. "Expedience of applying solar and wind hybrid power-plants in railway infrastructure objects". Procedia Engineering 134: 9-13. https://doi.org/10.1016/j.proeng.2016.01.030.

Yang, N., J. Pouget, T. Letrouvé, C. Jecu, and L. Joseph-Auguste. 2019. "Techno-economic design methodology of hybrid energy systems connected to electrical grid: An application of hybrid railway power substation". Mathematics and Computers in Simulation 158 (april): 107-19. https://doi.org/10.1016/j.matcom.2018.06.012.

Zhong, Z., Y. Zhang, H. Shen, and X. Li. 2020. "Optimal planning of distributed photovoltaic generation for the traction power supply system of high-speed railway". Journal of Cleaner Production 263: Article number 121394. https://doi.org/10.1016/j.jclepro.2020.121394. 